\title{
Timely and urgent
}

\author{
DEBORAH FRASER
}

\section{Review of Margaret MacDonald (2016), Elwyn Richardson and the Early World of Creative Education in New Zealand, NZCER Press.}

When the innovative teacher Elwyn Richardson wrote In the Early World (1964), teachers and scholars alike were inspired by what one teacher can achieve. His book brought to life the remarkable work that students can produce with the guidance of a talented teacher. Elwyn modelled the importance of curiosity, persistence, and ownership of learning. For decades teachers have turned to his seminal work to savour the vivid examples of students' artwork, literacy, science, and other pursuits. Margaret MacDonald's timely book on Elwyn Richardson is an important gift to educators at a time when teachers feel increasingly shackled by forces beyond their control.

Margaret's book on Elwyn peels back the layers on his teaching, providing new insights to his philosophy as an educator. It examines in a scholarly yet readable fashion the forces that contributed to his outstanding talent as a teacher. It brings us the man behind the innovation showing how a teacher's pedagogy is imbued with identity. Original photos throughout the text bring to life the rich, organic learning experiences his students pursued. The potent mix of time, place, person and history that contributed to Elwyn's work at Oruaiti seemed to be a perfect storm; the coalescing of the "right" teacher at the "right" time. But that is not the only story. There are deeper lessons for all educators in this book that are urgent.

This important book brings together the strands of influences that shaped Elwyn and more broadly, the landscape of education in New Zealand. Too few books have acknowledged the complex interface between personal identity and social, cultural and historical influences. We need this timely reminder of what is possible as teachers feel increasingly powerless. This book is neither romantic accolade nor polemic. It is a series of circling stories with the theme of hope, as relevant today as any time in the history of schooling.

Margaret contextualises Elwyn's teaching within education

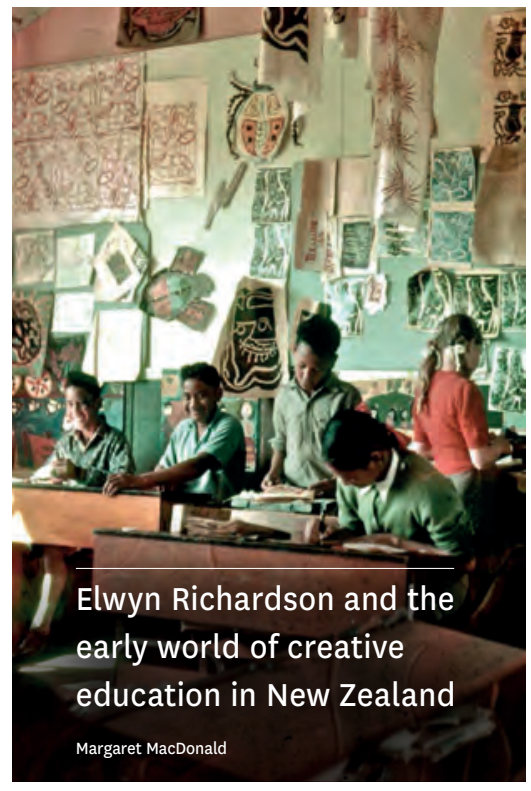
policy prior to and during his career. She reveals the historical influences on education in New Zealand, for instance the roots of progressive education, and discusses outstanding educational leaders such as Hogben, Beeby, Tovey, and Dewey whose ideas are timelessas relevant today as at any point in history. It is sobering to read that the issues these great thinkers grappled with are still problematic today and there is much to reflect upon in the light of current policy. For instance, do policy makers today consider the education of the whole child or are they distracted by data entries, achievement graphs, and measurement by standards? Do we value the legacy of outstanding teachers such as Elwyn and if so, where is the evidence 
of this in contemporary schools? Where are the artsand science-rich schools that integrate curriculum and capitalise on students' natural curiosity?

While many are tempted to think the best advances in education are contemporary there is much to learn from this book about the contributions of the past. For instance, at the start of the 1900s Dewey and Hogben (New Zealand's Inspector General of Schools until 1915) promoted the need for schools to fit to the nature of the child rather than the other way round. The value of the whole child was reflected in education policy, reflecting the humanist ideal of "a balance of the spiritual, moral, intellectual and physical faculties” (p. 38). The respect for the child as an active, capable agent has it roots in 18thand 19th-century philosophers and educational reformers such as Rousseau, Pestalozzi, and Froebel "all of whom were quoted liberally by school inspectors in their annual reports" (p. 38).

The arts were deliberately used as a Trojan horse in schooling to modernise teaching methods and underscore the importance of creativity. Margaret explains that in 1885, Stout (the first Minister of Education in New Zealand) made drawing "a compulsory 'pass' subject in the primary syllabus" (p. 29). Compare this with the marginal status of the arts today, relegated to the endangered species list despite compelling evidence to show that arts-rich schools have high levels of achievement across the curriculum. The book delves into the way in which the arts were a catalyst for educational reform for much of the first half of the 20th century. Beeby himself realised the potential of the arts to transform education and improve the world. Margaret also explores the influence of the progressive movement that began in the 1870s with its focus on equity, democracy and purposeful activity. Moreover, as long ago as 1929, the Syllabus of Instruction for Primary Schools in New Zealand includes an exhortation as important in 2016 as it was then:

It is hoped that the present syllabus will give encouragement to those teachers-and fortunately there are many of them-who regard the child not as inanimate clay in the hands of a potter or as an empty vessel sent to them for filling, but as a soul, a personality, capable of being developed and trained for the wider service of humanity. (cited in MacDonald, 2016, p. 51)

This quote reminds us to honour each student's unique individuality and that service to humanity is a moral goal of schools. The current thrust around assessment to achievement standards and measurement through recording copious amounts of data seems clumsy in the light of this noble statement. While teachers today do not consider the child as "empty" there is a distinct trend towards ignoring the soul of the child in preference for measuring and ranking. What damage is done to a child consistently ranked as "below standard"? The insidious effects of "below standard" ignores the spiritual and moral aspects of the learner, aspects that are equally if not more important than narrow measurements in numeracy and literacy. The child is not a soulless vessel sent to us to measure and rank. One could argue schools have always ranked students, but seldom at 5 years of age and in such condemnatory language.

The book also reminds us to take seriously what we bring to teaching. Teachers who share their keen interests, as Elwyn did, open a wondrous world for students; a world they may not ever experience as enticing if such a teacher did not provide both pathway and beacon. The thing we most recall about our favourite teachers is the passion they had for a certain field or fields, and such passion (along with pedagogical skill) is contagious. It is vitally important that teachers bring their own interests to teaching, revealing aspects of who they are and the satisfaction that comes from losing oneself in a subject; that delicious blurring of self and subject, which evokes depth of focus and appreciation. In so doing, teachers also give students license to bring who they are and what they cherish to the table of learning.

Another important lesson to be distilled from this book is we are freer than we think we are.

Elwyn expressed resentment towards the educational establishment yet there is evidence to suggest he had more supporters than he credited and his approach (like that of Ashton-Warner's) was embraced by many at the time. His identity as a lone wolf pushing the frontiers of education is evident, but so too is the way in which his innovations reflected the intent of the best education policy before and during his career. Even current policy for the most part, does not counter the innovation evident in Richardson's work. Elwyn realised education should enrich who we are and resonate with relevance. This book shows how he deliberately built the curriculum around the internal and external lives of his students. When teachers forge connections with students' lives like this, they create a meaningful curriculum. Such a connection helps teachers stay alert to what really matters in education. What matters is a curriculum that places students' natural curiosity at the heart so that they are encouraged to explore who they are and the world around them. Elwyn encouraged freedom to explore, opportunity to observe closely, and the discipline to record findings in various ways. He also upheld the value of the arts and science as dynamic means of expression and not secondary to other subjects. In addition, he realised that one subject informs another; that scientific understanding is enhanced by the aesthetic and vice versa. 
There are rich layers to this book. There is content for the historian, the policy maker, the philosopher, the teacher educator, the research student, the school leader, the classroom teacher, and the parent. Anyone involved in education needs to know this book and be nourished by its content. It contrasts markedly with the increasing commodification of education. Products in various guises are sold as the "next best thing" regardless of the social or cultural relevance for the students they are aimed at. We risk "discovering" concepts we mistakenly believe are new and cutting edge, without cognisance of the historical roots from whence these ideas first emerged. We risk superficial interpretation of complex educational ideas that have been debated over time. This book explores central tenets in education and associated debates on topics such as child-centred education, the role of the teacher, and children's art. Margaret skilfully iterates between the micro and the macro so the reader can appreciate the coalescing of the various influences at play.

What would Elwyn make of social media and students' employment of various digital devices in schools? As tools for exploring themselves and their world I suspect he would embrace them as he encouraged the use of microscopes, kilns, and maps. However, he would be understandably cynical about the recent trend for "modern" or "flexible" learning environments. Margaret shows how Elwyn decades ago developed multiple, flexible groupings and a differentiated curriculum with students determining the direction and assessment of their learning. His school and its surrounds reflected a plethora of student investigations and constructions such as testing different samples of clay for firing pottery to building their own brick kiln. For educators to claim new furniture and devices creates a quality learning environment misses the point. It is the quality of the teaching that takes place in any space that is the litmus test for whether an environment is conducive to learning or not. Taking down classroom walls and calling teachers facilitators does not magically improve teaching. Too many modern classrooms are saturated with superficial busy work masquerading as student-led inquiry. Unfortunately the quality of work produced in such rooms often falls short of anything Elwyn achieved with his students. While Elwyn referred to himself more as guide than teacher in traditional terms, he, like Dewey, did not allow any activity to count as learning. He challenged children to explore, ask questions, try things out, consider alternatives, craft and re-craft to produce high quality work: artwork worthy of exhibitions; science projects like those of real scientists; eloquent poetic and other writing the students published in their regular school magazine. This is teaching at its finest.

Teacher education has much to glean from Margaret's keen analysis. Woe betide us if we perpetuate ahistorical ideas that do not acknowledge the wealth of beliefs, policies and theories that have informed education. No teacher education programme can cover everything but we need to know about the finer aspects of our past; the people, policies and philosophies that have shaped us. We need to make conscious, as Margaret does, the rich soil from which our best ideas and practices came. If not, we risk a mediocre deference, or worse a seduction, by whatever latest trend is marketed the hardest by those who decide what counts as fashionable, regardless of its longevity and worth.

Thoughtful school leaders will see the merit of this book for staff development. It brings to life the people and policies that shaped and continue to shape excellent teaching in this country. It saves teachers from ahistorical, atheoretical stances in education that lead to superficial and ineffective programmes. It resuscitates the arts and places them centrally in the landscape of the curriculum. It provides vivid examples of scientific and literary works produced by inspired students. It rescues creativity from conformity, student ownership from transmission, curiosity from mindless busy-work, and genuine inquiry from the superficial. It liberates both teachers and students to become partners in creating, evaluating, revising, honing, questioning and producing quality work. It urges us to afford students the dignity of being taken seriously as writers, artists, scientists, and critics. Surely, this is what an education should provide.

\section{Postscript}

Margaret MacDonald's book is based on her PhD thesis. Her doctorate won the Sutton-Smith award for best doctoral study in 2011, bestowed by the New Zealand Association for Research in Education.

It is an exceptionally challenging job to convert a $\mathrm{PhD}$ into such an inviting book and Margaret succeeds in every respect.

\section{References}

Richardson, E. (1964). In the early world. Wellington: New Zealand Council for Educational Research.

Dr Deborah Fraser is a Professor of Education in Te Hononga, School of Curriculum and Pedagogy in Te Kura Toi Tangata, Faculty of Education at the University of Waikato. Her research interests include curriculum integration, the arts and creativity in schools.

Email: dfgfraser@gmail.com 